Egyptian J. of Phycol. Vol. 8, 2007

\title{
EVALUATION OF NUTRITIONAL COMPOSITION OF SOME ATTACHED AND DRIFTED MARINE ALGAE FROM ALEXANDRIA, EGYPT
}

\author{
Alaa Ahmed Fathy \\ Department of Botany, Faculty of Science, Muharram Beck, Alexandria University, \\ Alexandria, Egypt.
}

\begin{abstract}
Chemical composition of eight Egyptian marine macroalgae, Ulva lactuca and Enteromorpha linza (Chlorophyceae); Dictyota dichotoma, Sargassum vulgare and Cystoseira spinosa (Phaeophyceae); Pterocladia capillacea, Corallina officinalis and Jania rubens (Rhodophyceae), was determined. Water content in all algae analyzed was high $(>80.1 \%)$ especially in green algae. Ash content exhibits its highest values in the studied red algae. Total protein values varied within the different studied species, showing the highest value $(19.7 \%)$ in the red alga Pterocladia capillacea. The two green algal species (U. lactuca and E. linza) showed the highest soluble carbohydrates content (28.4 and $33.4 \%$, respectively). Crude lipids values represented very low percentage of the chemical composition of the studied algal species. The highest caloric values were recorded for U. lactuca and E.linza. Values of different chemical constituents of the drift algae analyzed were comparable with those values recorded for attached algal specimens. The results of this work support utilization of marine macroalgae as untraditional natural source of protein and carbohydrates. Also, the richness in nutritional composition in drift algae and the ease with which they collected, make it preferable to use them rather than using the attached algae.
\end{abstract}

\section{Introduction}

For many years, marine algae have been used world-wide in agriculture, nutrition and for pharmaceuticals due to their richness in minerals, vitamins and polysaccharides (Arasaki and Arasaki, 1983). The Japanese eat $1.4 \mathrm{Kg}$ per person per year. This ancient tradition and everyday habit has made possible a large number of epidemiological researches showing the health benefits linked to seaweed consumption (Teas 1981; Hiqashi et al., 1999). Currently, human consumption of green algae (5\%), brown algae $(66.5 \%)$ and red algae $(33 \%)$ is high in Asia, mainly Japan, China and Korea (Dawes, 1998). However demand for seaweed as food has now also extended to North America, South America and Europe (McHugh, 2003). In 2003, it was estimated that approximately one million ton of wet seaweed could be 
harvested annually in thirty five countries as a source of food; as source of agar; as a fertilizer; as fuel; and for use in cosmetics (McHugh, 2003).

Seaweeds are a valuable food source as they contain protein, lipids, vitamins and minerals (Marinho-Soriano et al., 2006).Seaweeds are not only a useful food source to humans, whole plants and seaweed mixes have been used in animal nutrition (Indergaard and Minsaas, 1991; Ventura and Castanon, 1998) and fish fed (McHugh, 2003).

The nutritional properties of seaweeds are poorly known and normally are evaluated from the chemical composition (Mabeau and Fleurence, 1993). There has been little publication on the quantitative studies of the nutritional composition in the Egyptian seaweeds (Abdel-Fattah and Edrees, 1973; Abdel-Fattah et al., 1978; Hussein et al., 1981). The aim of this study is to assess the basic nutritional composition of some common marine algae growing along the northern seashore of Alexandria. This information will be essential in the search for additional healthy food sources in efforts to assess the value of near shore natural resources in northern Egyptian coasts.

\section{Materials and Methods}

\section{Study site:}

Abu-Qir Bay is a semi-enclosed basin located about $36 \mathrm{~km}$ east of Alexandria. It lies between $30^{\circ} 05^{\prime}-30^{\circ} 22^{\prime} \mathrm{E}$ and $31^{\circ} 16^{\prime}-31^{\circ} 21^{\prime} \mathrm{N}$. This western inshore area of the bay is a shallow region (with average depth of $3.8 \mathrm{~m}$ ), interrupted with several rocky islets.

\section{Sampling and biomass estimation:}

Ulva lactuca, Enteromorpha linza (Chlorophyceae), Dictyota dichotoma, Sargassum vulgare, Cystoseira spinosa (Phaeophyceae), Pterocladia capillacea, Corallina officinalis and Jania rubens (Rhodophyceae) were randomly collected and then brought to the laboratory in dark plastic bags. In addition, several samples of drift algal species were cautiously collected and transported to laboratory in dark plastic bags. The collected samples were identified, washed with distilled water to remove epiphytes and impurities and weighed. The algal samples were dried at oven $\left(60{ }^{0} \mathrm{C}\right)$ till constant weight. The dried samples were weighted and ground into a fine powder. All chemical analyses were conducted in triplicate on dried ground material. All values were reported relative to the dry weight of the seaweed. Mean values and standard error were calculated. 
Evaluation of Nutritional Composition of Some Attached and Drifted Marine Algae from Alexandria, Egypt.

\section{Water content of fresh algae}

Algal water content was calculated by subtracting the dried sample weight from the wet weight for each sample.

\section{Algal ash determination}

Algal ash content was determined by heating 5 grams of each algal sample for $4 \mathrm{~h}$ at $550{ }^{\circ} \mathrm{C}$, kept in desiccators and reweighed. The ash content was determined using the following equation (Marsham et al., 2007):

Ash $\%=$ weight of ash $/$ Fresh weight of algal sample $\times 100$

\section{Total protein analysis}

The lowry method (Lowry et al., 1951) was used for protein determination. The algal samples were digested in $1 \mathrm{~N} \mathrm{NaOH}$, and then allowed to react with an alkaline copper citrate solution and Folin-Cioalteau phenol reagent. The protein content was determined by measuring the absorption at $660 \mathrm{~nm}$ using bovine serum albumin as standard.

\section{Soluble carbohydrate content}

Soluble carbohydrates were extracted from algal samples in 5\% trichloroacetic acid, and the concentrations were determined by using the phenolic sulfuric acid colorimetric method outlined in Dubois et al. (1956). Percent of soluble carbohydrate was calculated based on absorption at $490 \mathrm{~nm}$ using spectrophotometer, and compared to glucose as standard.

\section{Crude lipids analysis}

Crude lipid was extracted from algal samples in a chloroform-methanol (2:1, $\mathrm{v} / \mathrm{v})$ mixture, then purified and evaporated to dryness and weighted according to the method described in Chan et al. (1997).

\section{Calories:}

Calories value was calculated by the following equation (Márcia de Pádua et al., 2004):

Calories $\left(\mathrm{kcal} 100 \mathrm{~g}^{-1}\right)=4 *$ protein $(\%)+9 * \operatorname{lipid}(\%)+4 *$ carbohydrate $(\%)$.

\section{Results}

Measurable differences in nutritional composition were apparent among the studied species. Variation within species was slight. Water content of attached algal samples ranged from 80.1 to $89.1 \%$ for J. rubens and $U$. lactuca, respectively. Drift algae $C$. officinalis and $J$. rubens have the highest water content $(56 \%)$ Figure (1). Ash content of attached and drift algae were the most abundant constituents found in studied algal samples. Also C. officinalis have the highest ash content $66.2 \%$. 

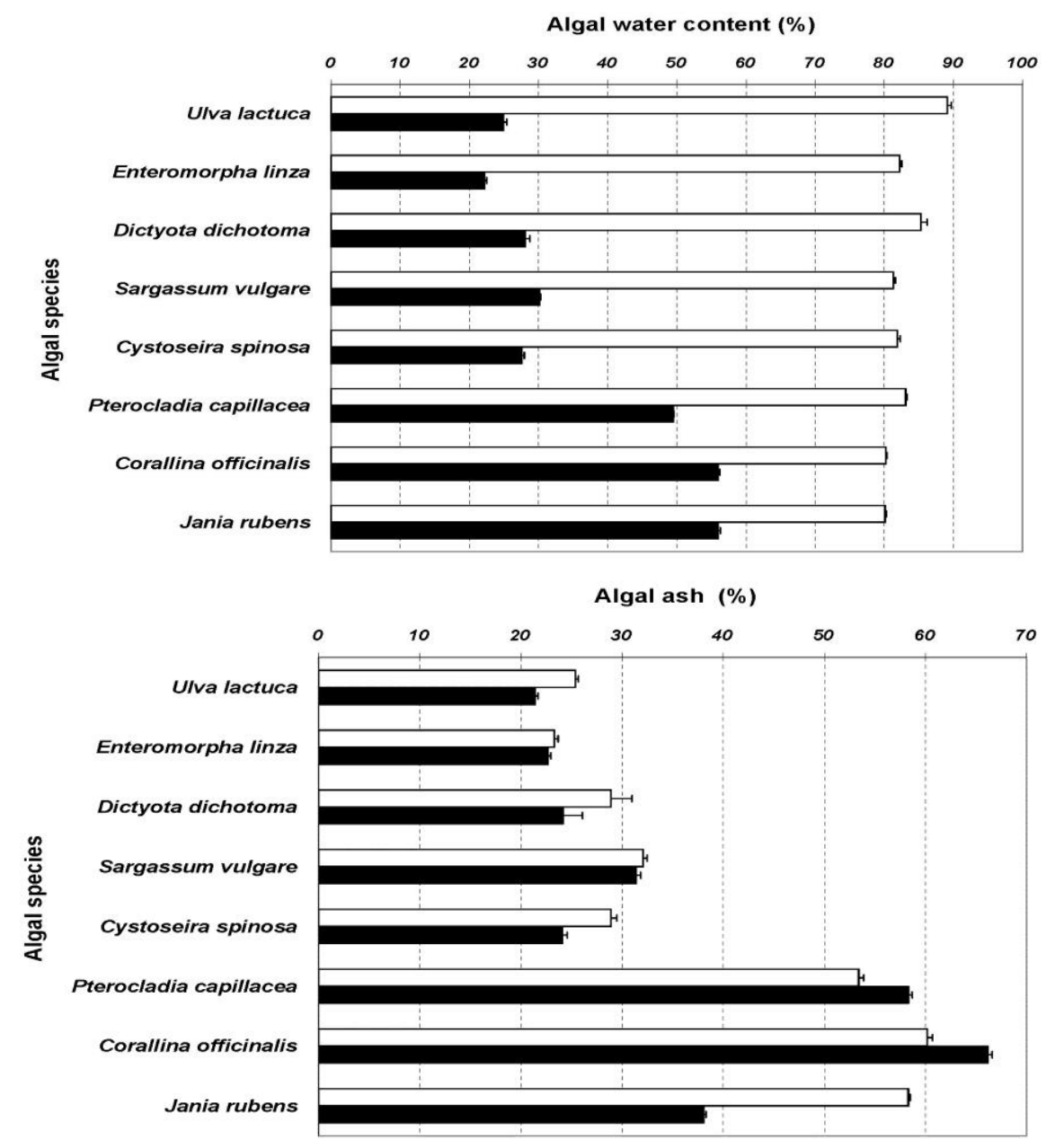

Figure (1): Water content (\%) and ash content (\%) in attached ( $\square$ ) and drift ( $\square$ ) algae.

Although values for the ash content of red algae showed a narrower range than other studied species, they showed the highest ash contents among the species analyzed (Figure 1).

The lowest total protein content values were recorded for the red algae $J$. rubens $(7.1 \%)$ and $C$. officinalis $(8.2 \%)$, while the highest values was recorded for the red algae $P$. capillacea (19.7\%) (Figure 2). 
Evaluation of Nutritional Composition of Some Attached and Drifted Marine Algae from Alexandria, Egypt.
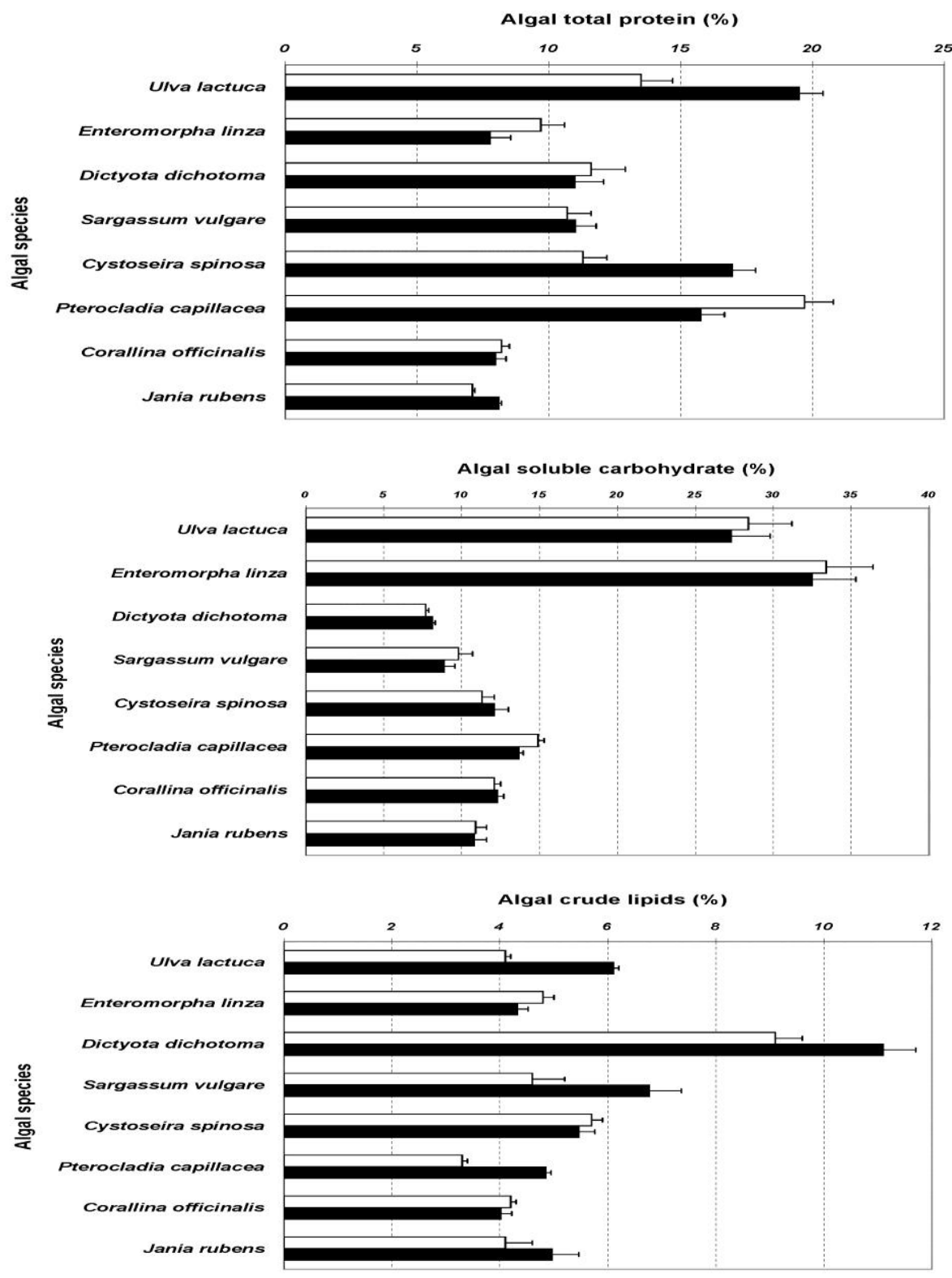

Figure (2): Total protein (\%), soluble carbohydrate (\%) and crude lipids (\%) in attached ( $\square$ ) and drift ( $\square$ ) algae. 
Soluble carbohydrate content showed their highest values in the green algae $U$. lactuca (28.4\%) and E. linza (33.4\%) (Figure 2), whereas the lowest values were recorded for the brown alga $D$. dichotoma $(7.7 \%)$. Soluble carbohydrates value of studied drift algae showed no noticeable difference from those recorded for attached algal samples. The carbohydrates values ranged from $8.1 \%$ for the drift brown alga $D$. dichotoma to a $32.5 \%$ for the drift green alga E. linza (Figure 2).The crude lipids content of all studied species was low except that value recorded the attached brown algae $D$. dichotoma $(9.1 \%$ ) (Figure 2$)$. The crude lipids content in the studied drift algae was comparable with the values of attached algae. The two green algae had a markedly higher caloric values. $U$. lactuca attained caloric value of $204.5 \mathrm{Kcal} 100 \mathrm{~g}^{-1}$

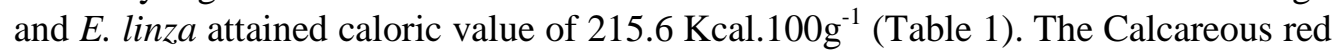
algae (J. rubens and C. officinalis) showed the lowest caloric content (108.9 and 119 $\%$, respectively). The green algae either attached or drift showed a remarkable caloric values compared with the other studied algae.

Table (1): Calories (kcal.100g-1) content of attached and drift algae.

\begin{tabular}{|l|c|c|}
\hline \multirow{2}{*}{ Algal species } & \multicolumn{2}{c|}{ Calories (Kcal.100g $\left.{ }^{-1}\right)$} \\
\cline { 2 - 3 } & Attached & Drift \\
\hline \multicolumn{2}{|c|}{ Chlorophyceae } \\
\hline Ulva lactuca & 204.5 & 242.1 \\
\hline Enteromorpha linza & 215.6 & 199.9 \\
\hline Dictyota dichotoma & 159.1 & 176.2 \\
\hline Sargassum vulgare & 123.4 & 140.3 \\
\hline Cystoseira spinosa & 141.7 & 165.3 \\
\hline \multicolumn{2}{|c|}{ Phaeophyceae } \\
\hline Pterocladia capillacea & 168.1 & 161.3 \\
\hline Corallina officinalis & 119 & 117.3 \\
\hline Jania rubens & 108.9 & 120.2 \\
\hline
\end{tabular}

\section{Discussion}

Fresh seaweeds collected from the sea consist of 70-90\% water (Jensen, 1993). This coincides with the results obtained in this study. The red species retained their water content much higher than the brown and green species which lost about 73 and $66 \%$, respectively, of their water content because of drifting. This may be because of Egyptian J. of Phycol. Vol. 8, $2007 \quad$ - 136 - 
the calcareous nature of $C$. officinalis and $J$. rubens and the leathery texture of $P$. capillacea which may prevent them from losing much of their water content after drifting.

Ash content of attached and drift algae were the most abundant constituents found in studied algal samples. This observation is in agreement with several previous reports on seaweeds (Wong and Cheung, 2001; Zubia et al., 2003; McDermid and Stuercke, 2003; Marsham et al., 2007). The lowest and highest ash values obtained in this study were comparable with those values reported for brown algae (Portugal et al., 1983; Robledo and Freile Pelegrin, 1997; Wong and Cheung, 2001a) and for species of green and red algae (Marsham et al., 2007; McDermid and Stuercke, 2003; Márcia de Pádua et al., 2004). Ash content of $U$. lactuca was comparable to other ash values reported for other species of Ulva (McDermid and Stuercke, 2003; Márcia de Pádua et al., 2004; Marinho-Soriano et al., 2006). Similarly, the ash content of E. linza was equal or lower than those values reported for other species of the same genus (McDermid and Stuercke, 2003). The brown seaweed S. vulgare showed ash content comparable with other Sargassum species (McDermid and Stuercke, 2003; Márcia de Pádua et al., 2004). Although the ash values of studied rhodophycean species attained the highest values among the species analyzed, still lower than those values obtained by McDermid and Stuercke (2003) working on 14 rhodophycean algae.

The protein content of brown seaweeds is generally small, whereas higher protein contents are recorded in green and red seaweeds (Burtin, 2003). The attached red alga $P$. capillacea and the drift green alga U. lactuca showed the highest total protein content among the algal species analyzed. The protein values of marine algae varied greatly from species to another in different taxonomic group or even within species of the same genus (McDermid and Stuercke, 2003; Márcia de Pádua et al., 2004; Dere et $a l ., 2003)$. There was no noticeable difference in protein content between the attached and drift algae in this study. However, the high proteins values in studied algae either attached or drift are comparable with the protein values recorded in other seaweeds in several pervious researches (Zubia et al., 2003; Marinho-Soriano et al., 2006). These findings encourage the use of green alga $U$. lactuca, the brown alga $C$. spinosa and the red alga $P$. capillacea for animal food, as a substitute for protein from other sources. Algal meal seems to have beneficial effects in fish diets e.g., improving disease resistance (Mustafa and Nakagawa, 1995). Such beneficial effects have been also observed for cow, sheep and poultry with the addition of algal supplements (Chapman and Chapman, 1980; Indergaard and Minsaas, 1991). Because of the high protein content of drift algae, which nearly equal to the values of attached algae, we 
suggest using the drift algae as economical natural protein source instead of using attached ones.

When comparing carbohydrate content of seaweeds, methods and semantics become an issue (McDermid and Stuercke, 2003). Some researchers measured 'total carbohydrates,' others 'soluble carbohydrates,' still others 'sugars and starches, etc.' In some studies, the carbohydrate content was calculated by subtracting the ash, protein, lipid and moisture from $100 \%$, and in others a colorimetric method was used for analysis. Arasaki and Arasaki (1983) stated that carbohydrates comprise 50-60\% of the dry weight of seaweeds. This study measured soluble carbohydrates colorimetrically, and found concentrations ranging from 7.7 to $33.4 \%$ in attached algae, and from 8.1 to $32.5 \%$ in drift algae, which coincide with the range obtained in the work of Kennish and Williams (1997) who reported soluble carbohydrates concentrations from 8.1 to $33.7 \%$ of the seaweeds dry weight. The green algae in this study exhibited the highest soluble carbohydrates content, which is in argument with the result obtained by Marinho-Soriano et al. (2006), who obtained the highest soluble carbohydrates in brown and red seaweeds. However, the results of this study in cope with the results obtained in Dere et al., (2003), where the highest soluble carbohydrates was recorded in green algae especially in Ulva and Enteromorpha linza.

Algae are not used as a conventional energy source because of their low fat in lipids (Zubia et al., 2003). The crude lipids content in the studied algae ranged from to 3.3 to $9.1 \%$, which is comparable with the range reported for other algal species (Zubia et al., 2003; Marinho-Soriano et al., 2006; Marsham et al., 2007). There was noticeable difference between crude lipids content of studied attached and drift algae. The green algae $U$. lactuca and E. linza (attached and drift) showed the highest caloric values among the studied algal species. Their caloric values were comparable with values recorded for Ulva lactuca (261.1 kcal $100 \mathrm{~g}^{-1}$ ) and Ulva fasciata (231.8 $\left.\mathrm{kcal} 100 \mathrm{~g}^{-1}\right)$ in the work of Márcia de Pádua et al. (2004).

\section{Conclusion}

1. From a nutritional standpoint, the main properties of seaweeds are their high protein and soluble carbohydrates.

2. According to the results obtained in this study, different chemical constituents of studied algae were not much affected by drifting.

3. The richness in nutritional components in drift algal species, beside the tedious efforts required to collect or/and cultivate attached seaweeds, support the use 
of drifted algae rather than attached ones as an untraditional natural source of protein and carbohydrate.

4. Although more research is needed to evaluate the nutritional value of marine algae, seaweeds can be regarded as an under-exploited source of health benefit molecules for food processing and neutraceutic industry.

\section{References}

Abdel-Fattah, A. F. and Edrees, M. (1973). Composition of some brown algae as influenced by seasonal variation, Phytochem., 9:721-724.

Abdel-Fattah, A. F.; Hussein, M. M. D. and Fouad, S. T. (1978). Carbohydrates of the brown seaweed Dictyota dichotoma. Phytochem., 17: 741-743.

Arasaki, S. and Arasaki, T. (1983). Vegetables from the Sea. Japan Publ. Inc., Tokyo. pp.196.

Burtin, P. (2003). Nutritional value of seaweeds. E. J. Environ. Agric. Food Chem., 2(4):498-503.

Chan, J. C. C; Cheung, P. C. and Ang, Jr. P. O. (1997). Comparative studies on the effect of three drying methods on the nutritional composition of seaweed Sargassum hemiphyllum (Turn.) C. Ag. L. Agric. Food Chem., 45:3056-3059.

Chapman, V. J. and Chapman, D. J. (1980). Seaweeds and their uses. $3^{\text {rd }}$ edition. Chapman and Hall, Lonodon, UK. pp. 334.

Dawes, C. J. (1998). Marine Botany. $2^{\text {nd }}$ edition, A Wiley interscience publications, John Wiley and Sons, Inc., New York, USA, p. 480.

Dere, S.; Dalkiran, N.; Karacaoğlu, D.; Yildiz, G. and Dere, E. (2003). The determination of total protein, total soluble carbohydrate and pigment contents of some macroalgae collected from Gemlik-Karacaali (Bursa) and ErdekOrmanli (Balikesir) in the Sea of Marmara, Turkey. Oceano., 45(3): 453-471.

Dubois, M.; Gilles, F. A.; Hamilton, J. K.; Rebers, P. A. and Smith, F. (1956). Colorimetric method for the determination of sugars and related substances. Anal. Chem., 28:350-356.

Hiqashi, O. S.; Otani, S. and Okai, Y. (1999). Potent suppressive effect of Japanese edible seaweed, Enteromorpha prolifera (Sujiao-nori) on inhibition and promotion phases of chemically induced mouse skin tumorigenesis. Cancer Lett., 140:21-25. 
Hussein, M. M.; Abdel-Aziz, A. and Salem, H. M. (1981). Composition of Enteromorpha intestinalis as influenced by seasonal variation. Egypt J. Bot., 24(2):131-135.

Indergaard, M. and Minsaas, J. (1991). Animal and human nutrition. In: Guiry M D; Blunder G (Eds.), Seaweed resources in Europe: Uses and Potential. John Wiley and Sons, pp. 22-64.

Jensen, A. (1993). Present and future needs for algae and algal products. Hydrobiol., 260/261:15-23.

Kennish, R. and Williams, G. A. (1997). Feeding preferences of the herbivorous crab Grapsus albolineatus: the differential influence of algal nutrient content and morphology. Mar. Ecol. Progr. Ser., 147:87-95.

Lowry, O. H.; Rosebrough, N. J.; Farr, A. L. and Randall, R. J. (1951). Protein measurement with the Folin phenol reagent. J. biol. Chem., 193:265-275.

Mabeau, S. and Fleurence, J. (1993). Seaweed in food products: biochemical and nutritional aspects. Trends in food sci.Techno., 4:103-107.

Márcia de Pádua, M.; Fontoura, P. S. G. and Mathias, A. L. (2004). Chemical composition of Ulvaria oxysperma (Kützing) Bliding, Ulva lactuca (Linnaeus) and Ulva fasciata (Delile). Braz. Arch. Biol.Techno., 1:49-55.

Marinho-Soriano, E.; Fonseca, P.C.; Carneiro, M. A. A. and Moreira, W. S. C. (2006). Seasonal variation in the chemical composition of two tropical seaweeds. Bioreso. Techno., 97:2402-2406.

Marsham, S.; Scott, G. W. and Tobin, M. L. (2007). Comparison of nutritive chemistry of a range of temperate seaweeds. Food Chem., 100:1331-1336.

McDermid, K. J. and Stuercke, B. (2003). Nutritional composition of edible Hawaiian seaweeds. J. Appl. Phyco., 15:513-524.

McHugh, D. J. (2003). A guide to seaweeds industry, FAO Fisheries Technical paper, No. 441. Rome, FAO, p. 105.

Mustafa, M. G. and Nakagawa, H. (1995). A review: dietary benefits of algae as an additive in fish feed. Isr. J. Aquacult., 47:155-162.

Portugal, T. R.; Ladines, E. O.; Ardena, S. S.; Resurreccion, L.; Medina, C. R. and Matibag, P. M. (1983). Nutritive value of some Philippine seaweed. Part II. Proximate amino acid and vitamin composition. Phili. J. Nut., 36:166-172.

Robledo, D. and Freile-Pelegrin, Y. (1997). Chemical and mineral composition of six potentially edible seaweed species of Yucatán. Bot. Mar., 40: 301-306.

Egyptian J. of Phycol. Vol. 8, $2007 \quad$ - 140 - 
Teas, J. (1981). The consumption of seaweed as a protective factor in the etiology of breast cancer. Med. Hypotheses., 7:601-613.

Ventura, M. R. and Castanon, J. I. R. (1998). The nutritive value of seaweed (Ulva lactuca) forgoats. Small Ruminant Res., 29:325-327.

Wong, K. and Cheung, P. C. (2001). Influence of drying treatment on three Sargassum species. Proximate composition, amino acid profile and some physic-chemical properties. J. Appl. Phycol., 13:43-50.

Zubia, M.; Payri, C. E.; Deslandes, E. and Guezennee, J. (2003). Chemical composition of attached and drift specimens of Sargassum mangarevense and Turbinaria ornate (Phaeophyta: Fucales) from Tahiti, French Polynesia. Bot. Mar., 46:562-571.

\section{تقييم التركيب الغذائي لبعض الطحالب البحرية المتصلة و المنجرفة من الإسكندرية (مصر) علاء فتحي قسم النبات كلية العلومجامعة الإسكندرية}

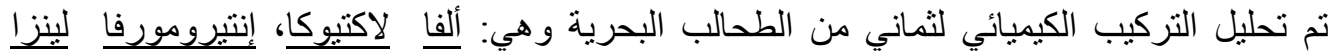

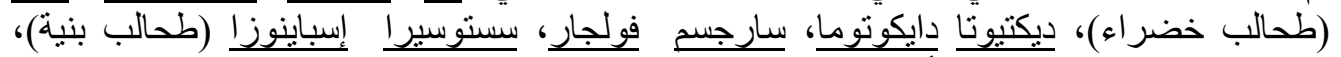

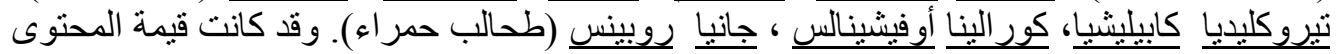

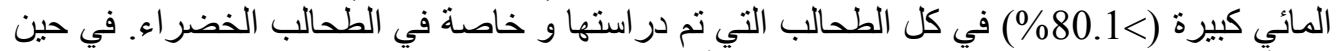

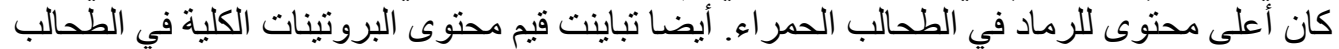
محل الدراسة، وقد سجلت أعلى محتوى للبروتينات (19.7\%) في الطي الطحلب الأحمر (تنيروكليديا

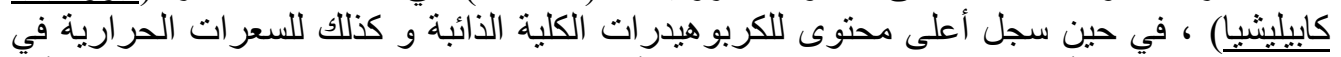

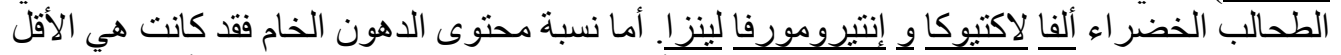

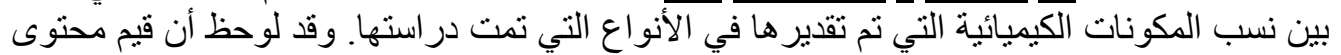

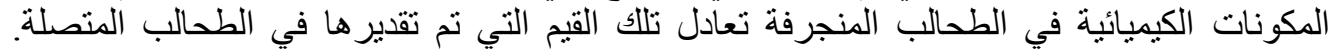

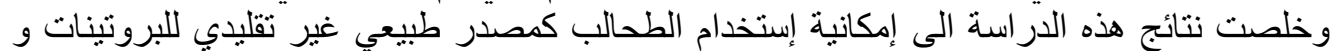

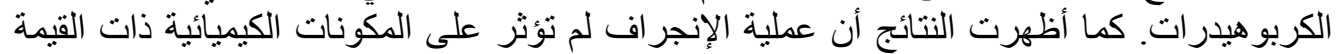

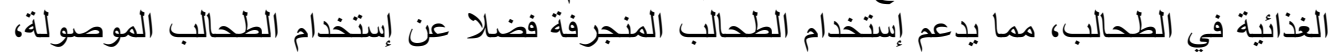

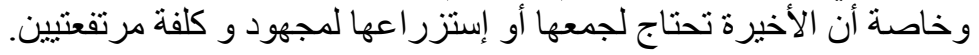

